\title{
HUMANITARIAN CRISIS: UNACCOMPANIED MIGRANT MINORS FROM CENTRAL AMERICA TO THE US - MEXICAN BORDER
}

\begin{abstract}
In June 2014, the border between Mexico and the United States (US) witnessed the arrival of more than 50,000 unaccompanied children from Central America trying to get to the US in order to join their parents, escape from different types of abuse and violence, or find new opportunities. The growing number of children in the border has developed a humanitarian crisis involving many actors, such as the children, the American government, the US border state governments, the Mexican government, the governments of Central America and many NGOs concerned by the problematic situation. The current paper seeks to analyze the origin and development of the crisis, as well as its consequences, and the actions that the actors mentioned above have taken, or not.
\end{abstract}

\section{Key words}

Mexican border, unaccompanied migrant minors, migration, Central America

\section{Introduction}

Immigrant flows from troubled countries from Latin America to the US have been part of a long and complex process through recent history, characterized by the constant and increasing number of people who decide to find new job opportunities or want to reach "the American dream". Its complexity lies in the

* Almendra Ortiz de Zárate Béjar, Leventis-Anahuac Chair on Cyprus Studies, Global Studies Faculty, School of Global Studies, Universidad Anáhuac México Norte.

** Yoanna Shubich Green, Faculty of Global Studies Universidad Anáhuac México Norte. 